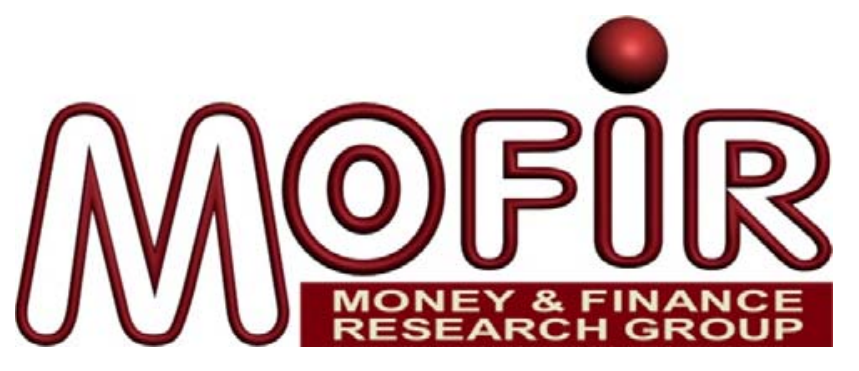

\title{
TOTAL PUBLIC DEBT AND GROWTH IN DEVELOPING COUNTRIES
}

\author{
ANDREA F. PRESBITERO \\ Università Politecnica delle Marche, Department of Economics \\ MoFiR \\ CeMaFiR
}

MoFiR working paper $n^{\circ} 44$

October 2010 


\title{
TOTAL PUBLIC DEBT AND GROWTH IN DEVELOPING COUNTRIES
}

\author{
Andrea F. Presbitero*
}

March 31, 2011

\begin{abstract}
The global crisis and the expansionary government reaction in many countries has revamped the attention of policy makers and academics on the growth effects of large public debts. Recent empirical studies investigate the impact of public debt on growth in advanced and emerging countries. This paper aims at complementing the existing evidence focusing on developing countries, where the increase in domestic borrowing, already started before the crisis, requires a more comprehensive analysis, based not only on external debt, but on total public debt. Results on a panel of low- and middle-income countries over the period 1990-2007 show that public debt has a negative impact on output growth up to a threshold of 90 percent of GDP, beyond which its effect becomes irrelevant. This non-linear effect can be explained by country-specific factors since debt overhang is a growth constraint only in countries with sound macroeconomic policies and stable institutions.
\end{abstract}

JEL Classification: F33, F34, F35, O11

Key words: Domestic debt, Public debt, growth.

\footnotetext{
*Andrea F. Presbitero, Department of Economics - Università Politecnica delle Marche (Italy), Money and Finance Research group (MoFiR) and Centre for Macroeconomic and Finance Research (CeMaFiR). E-mail: a.presbitero@univpm.it; personal webpage: https://sites.google.com/site/presbitero/. I wish to thank Tito Cordella, Michele Fratianni, Bernhard Gunter, Douglas Hostland, Camelia Minoiu, and Luca Papi and participants at the 2011 CSAE Conference (Oxford, 2011) and a seminar at the University of Milan for insightful suggestions.
} 


\section{Introduction and related literature}

The global crisis and the expansionary government reaction in many countries, culminated in a fast-growing US government debt and in unsustainable public debts in some European countries (notably Greece and Ireland), has revamped the attention of practitioners, policy makers and academics on the adverse effects of a large public debt. On March 2010, the Bank for International Settlements defined as unsustainable the prospects of public debt in several industrialized countries (Cecchetti, Mohanty and Zampolli, 2010). Similarly, on September 2010, the International Monetary Fund (IMF) released three position papers on unsustainable debt levels in advanced economies and its director of Fiscal Affairs Department, Carlo Cottarelli, said that "public debt levels among advanced economies have reached levels not seen before in the absence of a major war". Other than the relationship between government debt and crisis, largely explored by the literature (Panizza and Levy Yeyati, 2010), also the knowledge of whether, when and to what extent public debt impinges on economic growth (even without a default) is a critical issue in the debate on fiscal policy between who supports a strong fiscal stimulus to sustain the aggregate demand and who invokes the long-run adverse consequences of budget deficits and government debt. While the vast majority of commentators and the few recent academic papers on this subject (Reinhart and Rogoff, 2010b) deal predominantly with industrialized countries, as also the political debate does, this paper argues that a growing public debt might be a source of concern also for several low- and middle-income countries. Since the 1990s, a number of developing and emerging countries started substituting external with domestic debt (Panizza, 2008): between 1990 and 2004, the share of domestic debt in total public debt increased from 38 to 58 percent in a sample of 25 large emerging countries (Hanson, 2007), and domestic debt increased substantially also in low-income countries, many of whom benefited from debt relief (Arnone and Presbitero, 2010). Because of the 2007 global financial crisis, in addition to this trend, developing countries have to deal with a deteriorating fiscal balance due to growing public spending and lower revenues ${ }^{1}$.

The economic literature has investigated many channels through which a growing public debt might hamper long-run growth prospects in developing countries, particularly focusing on foreign borrowing. First, a large public debt might create debt overhang, a situation in which investment are reduced or postponed since the private sector anticipates that the returns from their investment will serve to pay back creditors (Krugman, 1988; Sachs, 1989). Besides, a high level of public debt can have adverse consequences on the macroeconomic stability (Singh, 2006), discouraging capital inflows while favoring capital flight (Alesina and Tabellini, 1989; Cerra, Rishi and Saxena, 2008), and increasing the incumbent politicians' incentive to "gamble for redemption", leading to higher policy volatility (Malone, 2010). Even if total investment does not lower significantly, the overall productivity can, since the uncertainty on future government actions to meet burdensome debt obligations might push investors to prefer short-term and low-risk investment to long-term and risky projects (Fosu, 1996; Serven, 1997). The private sector could also face more binding financing constraints since, particularly in countries with a significant share of domestic debt and underdeveloped financial markets, credit rationing can be the result of reduced savings, of increasing interest rates and of the banks' preference for risk-free government securities (Christensen, 2005; Hanson, 2007; Harrabi, Bousrih and Salisu, 2007). Other than debt stock, also the associated payment flows might impinge on growth and investment: debt service in several countries soaks up a significant amount of (scant) government revenues, reducing the available resources to fund (much needed) public investment in infrastructure (Cohen, 1993). The crowding out effect, while not always applicable to external debt

\footnotetext{
${ }^{1}$ The IMF calculates that the fiscal balance in emerging and developing economies decreased from 0.51 in 2007 to -4.37 in 2009 (International Monetary Fund, 2010).
} 
to poor countries, given the high degree of loan concessionality and the low repayment rates, is much more likely to work when considering total public debt, given a larger interest bill on domestic debt (Arnone and Presbitero, 2010).

On the empirical side, however, the evidence is quite limited and it generally deals exclusively with public external debt in low- and middle-income countries. Several studies were produced as a reaction of two waves of (external) debt crisis, the first affecting several Latin-American countries in the 1980s (Green and Villanueva, 1991; Savvides, 1992) and the second concerning the debt relief policies which targeted a number of heavily indebted and poor countries (HIPC) (Arnone and Presbitero, 2010; Cordella, Ricci and Ruiz-Arranz, 2010). The focus on foreign borrowing, while going back to Keynes' discussion of Germany's war reparations, can not be justified by the relative frequency of debt crisis related to either external or domestic debt, as recently pointed out by Reinhart and Rogoff (2009): over the long time span 1800-2006, as well as over the shorter period 1940-2006, the incidence of default on debt to domestic and foreign creditors was not statistically different. The focus of empirical research on external debt can be ascribed to the lack of available and reliable comparable data on domestic debt for a large sample of countries. Poor data availability, however, can be itself due to the limited interest of international financial institutions, at least until few years ago, on the issue of domestic debt in emerging and developing countries and to the lack of transparency of many governments in publishing time series data on domestic debt (Reinhart and Rogoff, 2009).

Notwithstanding a widespread data limitation, some recent efforts in collecting comparable figures on public debt makes possible to try to uncover the growth effect of total public debt. Abbas and Christensen (2010) complement the vast literature on external debt and growth finding that, in a panel of low-income countries and emerging markets, moderate levels of domestic debt have a positive contribution to GDP growth, as a result of the development of financial markets, increased private savings, better institutions and political accountability, and improved monetary policy. However, as long as the stock of domestic debt becomes too large (above the 35 percent of bank deposits), its contribution to economic growth turns negative, because of inflationary pressures and of the crowding out of the private sector ${ }^{2}$. Few other studies look directly at total public debt. Reinhart and Rogoff (2010b) analyze an impressive dataset on domestic and external debt covering 44 countries for over two centuries ${ }^{3}$ and find that government debt is unrelated to economic growth as long as it does not exceed 90 percent of GDP; beyond this threshold, the growth rate of highly indebted countries is significantly lower of that of countries whose public debt is below $90 \%$. This non-linear effect, which is difficult to point out with standard linear regression models, is present for both advanced and emerging economies. However, Reinhart and Rogoff (2010b) do not carry out any empirical analysis to sort out the direction of causality, arguing that for high levels of debt the causality should be bi-directional (Reinhart and Rogoff, 2010a) ${ }^{4}$. Similar findings are presented by Caner, Grennes and KoehlerGeib (2010): averaging data for a large sample of industrialized and developing countries over the period 1980-2008, Caner, Grennes and Koehler-Geib estimate a public debt threshold at $77 \%$ of GDP, lowered at 64 percent for developing economies; the non-linearity in debt effect on growth means that for moderate debt levels an increase in the public debt-to-GDP ratio helps expanding investment and translates in faster growth, while above the threshold additional debt reduces output growth. Albeit improving on Reinhart and Rogoff (2010b) thanks to the endoge-

\footnotetext{
${ }^{2}$ In a cross-country analysis, Arnone and Presbitero (2010) provide evidence of a negative correlation in a sample of developing countries between the initial level of domestic debt (as a share of GDP) and subsequent economic growth.

${ }^{3}$ The dataset is discussed extensively in Reinhart and Rogoff (2009).

${ }^{4}$ In the same vein, an earlier analysis by Blavy (2006) also uncovers a non-monotonic relationship between public debt and total factor productivity in a panel of 35 emerging economies; in this case, however, the threshold is much lower.
} 
nous threshold estimation, this approach still does not take into account endogeneity, an issue addressed by Kumar and Woo (2010), who find that public debt has a linear negative effect on subsequent GDP growth, TFP and investment. Other than being statistically robust across different econometric specifications, the growth effect of public debt is economically relevant: a $10 \%$ increase in the debt-to-GDP ratio is associated with a reduction of 0.2 percentage points of annual per capita real GDP growth. Moreover, consistently with Reinhart and Rogoff (2010b) and Caner, Grennes and Koehler-Geib (2010), also Kumar and Woo (2010) find some evidence of non-linearity in the debt effect on growth, which seems to be effective only when public debt exceeds 90 percent of GDP. However, their analysis is limited to a short time horizon and covers a limited sample of 38 advanced and emerging economies.

This paper builds on this literature and contributes along different issues. First, differently from the development literature, we consider the growing role of internal borrowing looking explicitly at the effect of total public debt on output growth. Second, diversely from the papers discussed above and focusing on total debt, this one looks directly at poor countries: the partial correlation between initial total public debt and subsequent per capita GDP growth is estimated in a large sample of low- and middle-income countries. Third, in addition to the contribution by Reinhart and Rogoff (2010b) and Caner, Grennes and Koehler-Geib (2010), this paper tries to uncover possible non-linearities in a multivariate setting and adopting different econometric techniques. Finally, the presence of possible sources of heterogeneity in the growth effect of public debt is assessed looking at the impact of public debt conditioned to country's policies and institutional quality. With respect to the latter point, we argue that there are sound reasons to expect debt overhang to be a binding constraints to investment and growth only in countries with sound macroeconomic policies and institutions, while in countries with volatile policies and lousy institutions, the latter are likely to hamper GDP growth, not debt, whose effect is overshadowed and becomes statistically irrelevant (Arslanalp and Henry, 2006; Presbitero, 2008; Cordella, Ricci and Ruiz-Arranz, 2010; Arnone and Presbitero, 2010) ${ }^{5}$. In a similar vein, the recent literature on financial globalization and economic growth suggests a non linearity in the effect of capital flows on growth, according to which financial integration might benefit only countries which have already implemented sound macroeconomic policies and reached a stable institutional setting (Arteta, Eichengreen and Wyplosz, 2003; Kose et al., 2009; Cline, 2010; Kose, Prasad and Taylor, 2010). Hence, only in those countries debt can impact on economic conditions. Consistent with the threshold hypothesis, there is some recent empirical evidence showing that a certain level of institutional quality in heavily indebted countries is required to attract foreign investment, stimulate economic growth and benefit from debt relief (Asiedu, 2003; Dessy and Vencatachellum, 2007; Harrabi, Bousrih and Salisu, 2007), suggesting that public debt affects the economic conditions of countries with good policies and institutions.

The remainder of the paper is as follows: the next Section introduces the dataset and its sources along with the main variables; Section 3 discusses the results, focusing firstly on some descriptive evidence supporting the necessity to look at total public debt (3.1), then presenting the main econometric findings (3.2) and finally showing some robustness exercises (3.3). Section 4 concludes drawing some policy implications for the International Financial Institutions.

\section{Data and methodology}

The empirical exercise is carried out merging macroeconomic data from several different sources for a sample of 92 low- and middle-income countries, listed in Table 1, over the period 1990-

\footnotetext{
${ }^{5}$ Throughout the paper we refer to good/bad and strong/weak policies and institutions in a relative sense, considering that the institutional setting and the macroeconomic framework of the average country in the sample is far from ideal.
} 
2007. Table 2 reports the definition, sources and summary statistics of all the variables. To wash out possible business cycle fluctuation, data are averaged over six non-overlapping threeyears periods. The main source for the macroeconomic variables are the World Development Indicators published by the World Bank, while data on total public debt are taken from the dataset collected by Panizza $(2008)^{6}$. To take into account the issue of reverse causality, in the same vein of Presbitero (2008) and Cordella, Ricci and Ruiz-Arranz (2010), the debt-to-GDP ratio ( $P U B L I C D E B T$ ) is measured in the first year of the three-years period and is built dividing total public debt by the smoothed GDP obtained applying the Hodrick and Prescott (1997) filter ${ }^{7}$.

The equation to be estimated is a basic growth model including the main variables suggested by the Solow (1956) model plus some other standard controls and augmented with the measure of public indebtedness (PUBLIC DEBT):

$$
G R O W T H_{i, t}=\alpha G D P_{i, t-1}+\gamma P U B L I C D E B T_{i, t}+X_{i, t} \beta^{\prime}+\eta_{i}+\tau_{t}+\epsilon_{i, t}
$$

where the lagged value of GDP $\left(G D P_{t-1}\right)$ measures conditional convergence and $X$ is a vector of standard control variables including: the log of the investment rate (INVESTMENT), the $\log$ of the gross primary enrollment rate as a measure of human capital accumulation $(H U M A N C A P I T A L)^{8}$, the overall CPIA score to take into account the role of policies and institutions (CPIA) on economic development (Acemoglu and Robinson, 2010) ${ }^{9}$, the sum of imports and exports of goods and services over GDP as a measure of openness (OPENNESS), and the standard deviation of inflation over the three-years windows (INFLATION) as a proxy for the degree of economic uncertainty. Finally, $\eta_{i}$ and $\tau_{t}$ capture respectively the country and time fixed effects, measured by geographic and time dummies, and $\epsilon_{i, t}$ is the classical spherical error term.

To take into account country fixed-effects, the endogeneity of the right-hand side variables and the dynamic structure of the model, we estimate equation 1 by Generalized Method of Moments (GMM) techniques. Following a growing literature which applies GMM to panel growth regression (Durlauf, Johnson and Temple, 2005), we use the two-step System GMM with the Windmeijer (2005)'s finite-sample correction for the covariance matrix, which has been shown to be more efficient than the one-step estimator (Roodman, 2009a) and to perform better than the Differenced-GMM and the within-group estimators (Hauk and Wacziarg, 2009) ${ }^{10}$. The SystemGMM exploits additional moment conditions since it consists of a system of two simultaneous

\footnotetext{
${ }^{6}$ These data such as others used to construct the final dataset, are publicly available at the website http://sites.google.com/site/md4stata/ (Catini, Panizza and Saade, 2010).

${ }^{7}$ Even if it received several criticisms, the HP filter withstood the test of time and is a standard method for removing trend (Ravn and Uhlig, 2002). Given the annual frequency of GDP data, the smooth parameter is set equal to 6.25 , accordingly to what suggested by Ravn and Uhlig (2002).

${ }^{8}$ According to the basic and augmented Solow model (Mankiw, Romer and Weil, 1992) and to the empirical findings by Levine and Renelt (1992), the growth rate of population should also be included and secondary education should be taken as a measure of investment in human capital instead of primary education. Instead, we choose this specification since population growth is always not significant and primary education is likely to be more informative in low- and middle-income countries (Kalaitzidakis et al., 2001). However, the main findings do not change relaxing this assumptions (see Section 3.3).

${ }^{9}$ The CPIA score is a composite index measuring the extent to which country policies and institutions create a good environment for growth and poverty reduction. The CPIA indicators are developed by the World Bank and reflect its staff professional judgment, based on country knowledge, policy dialogue, and relevant publicly available indicators. To overcome criticisms related to lack of transparency and objectivity, in 2004 the CPIA process and methodology were extensively reviewed by an external independent panel and, starting from 2005, these data are fully disclosed and published in World Development Indicators. The broad coverage - the CPIA overall score is available for 136 countries - and the long time horizon (data go back to 1977) makes this indicator very useful for empirical analysis based on panel data (International Development Association, 2007).

${ }^{10}$ For an extensive review of the empirics of economic growth using panel data, see Durlauf, Johnson and
} 
equations, one in levels and the other in differences, which takes, respectively, lagged first differences and lagged levels as internal instruments (Blundell and Bond, 1998). To avoid problems related to the proliferation of instruments, which in small samples are likely to overfit endogenous variables and to weaken the informative power of the Hansen test (Roodman, 2009b), we follow the rule of thumb according to which the number of instrument should be close to the number of countries (Roodman, 2009a) and limit the number of lags of endogenous variables to $t-1$ and $t$ - $2^{11}$. As additional external instruments, we include: 1) the La Porta et al. $(1997 ; 1998)$ categorical variable identifying the legal origin of the Company Law or Commercial code of each country (LEGAL ORIGINS) and 2) the Alesina et al. (2003) measure of ethnic fractionalization (ETHNIC FRACTIONALIZATION), which are both shown to affect the quality of government and policies, regulation and economic outcomes (Alesina and Ferrara, 2005; La Porta et al., 2008)

While we start modeling the debt-growth relationship as linear, we further test for the presence of a non-monotonic effect, as implied by the debt overhang hypothesis and consistently with the recent evidence on thresholds effects showed by Cordella, Ricci and Ruiz-Arranz (2010); Reinhart and Rogoff (2010b). Non-linearities are modeled is different ways. We first impose a quadratic functional form to detect an hump-shaped relationship between debt and growth, even if this procedure might be weakened by the presence of outliers. Thus, we also adopt a less parametric approach, estimating a spline specification with one or two discontinuity points (Marsh and Cormier, 2002). Finally, we try to sort out possible heterogeneous effect of public debt on growth according to country's policies and institutions interacting PUBLIC DEBT with the overall CPIA score (Presbitero, 2008) ${ }^{12}$.

\section{Results}

\subsection{Descriptive evidence: the increasing role of domestic debt}

The necessity to look at total public debt instead that focusing exclusively on external debt is testified by the fact that, since 1990, domestic debt in the whole sample of developing countries was larger than external debt. While looking at foreign borrowing could have been a good approximation of overall indebtedness in low-income countries, especially because of poor data quality on internal financing, the same is not true for middle-income countries (Figure 1). On the whole, external public debt declined in the last two decades, while domestic debt increased since 1995 up to 2003, when a process of deleveraging started in several countries, just before the recent increase in public debt started in 2007, not shown in the graph, but reported by Reinhart and Rogoff (2010b). On the whole, internal borrowing does not eliminates the exchange rate risk that a devaluation could trigger a debt crisis, but it generally comes with higher interest rates (especially for low-income countries which were able to borrow at concessional terms from multilateral development banks), increasing the possible crowding out effect (Hanson, 2007).

Looking at single countries provide additional insight on the increasing role of internal borrowing: in Figure 2 we report the evolution of domestic and external public debt over the period

${ }^{11}$ For robustness, we also show the estimates obtained collapsing the instruments set; see Section 3.3.

${ }^{12}$ We choose not to estimate the endogenous threshold according to the methodology proposed by (Hansen, 2000) and implemented also by Cordella, Ricci and Ruiz-Arranz (2010) since this procedure does not consent to take into account the endogeneity issue. We believe that the latter is the most important problem in this kind of exercise and in the trade-off between the two competing aims, we choose to deal with endogeneity. However, we can limit the arbitrariness implied by the spline approach, at least partially circumventing the impossibility to endogenously estimate the debt thresholds, running several spline specifications and choosing the ones the fit best the data.
} 
1990-2009 in four different countries, representing different levels of income and geographical regions. Jamaica is one of the most indebted countries in the world with a stock of public debt amounting to USD 16 billion (around 128 percent of GDP), almost equally divided between domestic and external debt. The historical evolution of public debt in Jamaica shows some sort of substitution effect between external and domestic debt, with the latter increasing substantially since 1993 and especially in response to the 1995 financial crisis which boosted government expenditures. The shift from external to domestic debt is associated with a decline in public investment and the large public debt seems to be a reason for low productivity (Blavy, 2006; Presbitero, 2010). A similar pattern is observable also in Sri Lanka: since 1990 total public debt remained almost stable around $90-100 \%$ of GDP, but the relative weight of domestic debt increased from 40 to $60 \%$. The relative importance of domestic borrowing in total public debt is exemplified also by the huge increase in Turkish domestic debt - from $22 \%$ to $51 \%$ in one year - after the 2000-2001 financial crisis which was followed by a contraction of public external debt. Finally, Ghana, where domestic debt became larger than external debt, exemplifies the situation of many heavily indebted poor countries (HIPC), where the sharp decline in external debt, due to the HIPC and the Multilateral Debt Relief Initiatives, is partially offset by a rising domestic debt (Arnone and Presbitero, 2010).

Figure 1: Domestic and external public debt in low- and middle-income countries

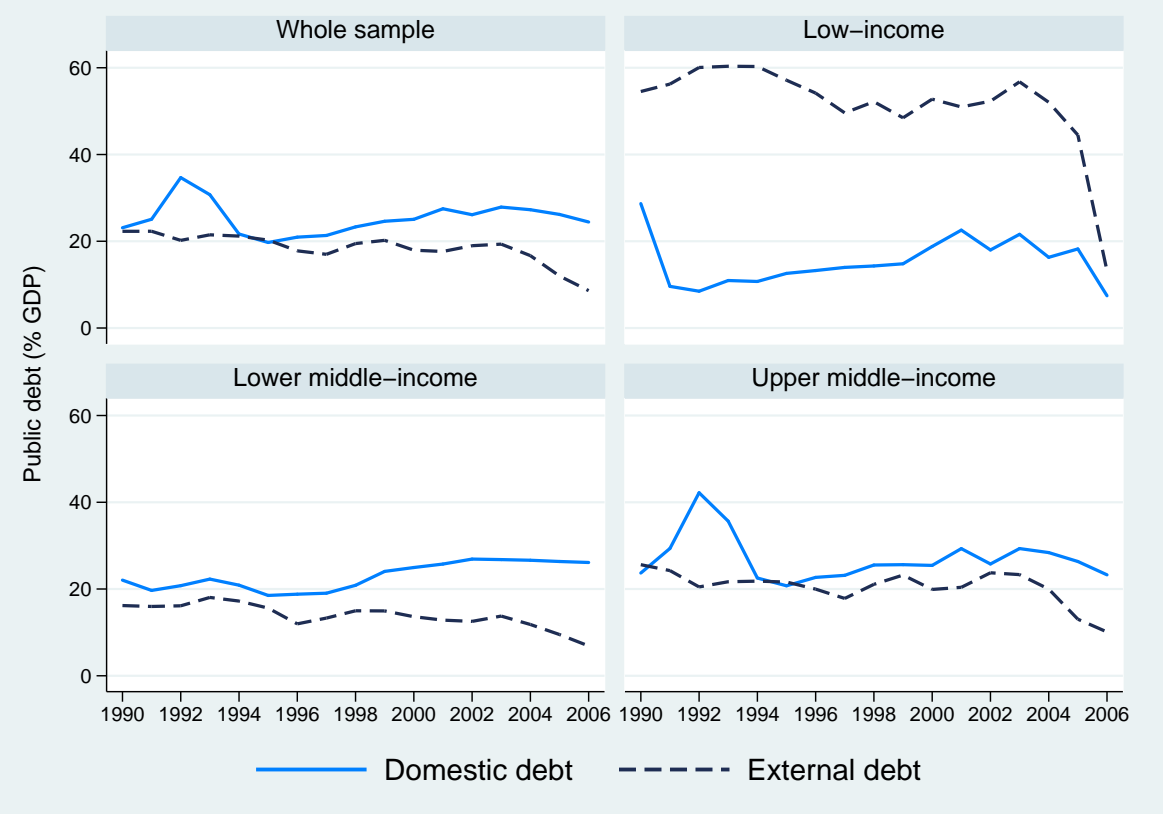

Calculations based on data on public debt in 104 developing countries compiled by (Panizza, 2008) over the sample period 1990-2006. Not all countries are in the panel for the whole period. The income classification include 26 low-income, 42 lower middle-income and 36 upper middle-income countries. Debt ratios are weighted averages by country's GDP.

\subsection{Multivariate analysis: public debt and subsequent growth}

The results of the two-step System-GMM estimation of model 1 are reported in Table 3. The coefficient on the control variables and the p-values of the diagnostic tests are quite stable across the different model specification, so we comment on them once for all. The diagnostic tests reported at the bottom of the Table support the model's specification: the Hansen-J 
Figure 2: Domestic and external public debt in selected countries

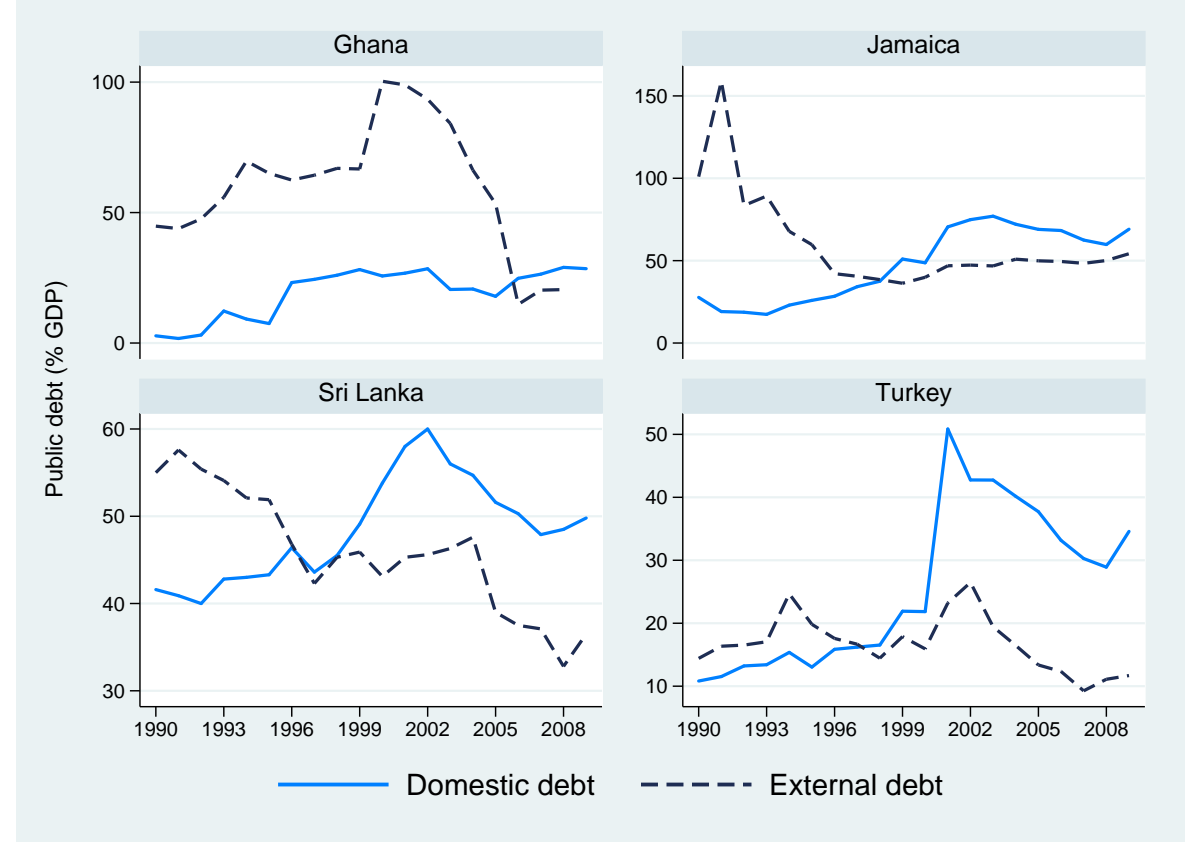

Calculations based on data on public debt ratios over GDP drawn from different sources. Data on Ghana are taken from several IMF Article IV (for government domestic debt) and from the 2010 World Development Indicators database (for public and publicly guaranteed external debt). Data on Jamaican public debt are published by the Debt Management Unit at the Ministry of Finance and the Public Service. Data on Sri Lanka's outstanding government debt are published by the national Central Bank. Data on central government domestic and external debt for Turkey are drawn from Turkish Undersecretariat of Treasury.

statistic does not reject the Over-Identifying Restrictions (OIR), confirming that the internal and external instruments can be considered valid, and the Arellano and Bond (1991) tests for serial correlation reject the null hypothesis of not autocorrelation of the first order and do not reject the hypothesis of no autocorrelation of the second order.

Consistently with expectations and past evidence (Levine and Renelt, 1992; Kalaitzidakis, Mamuneas and Stengos, 2000), there is evidence of conditional convergence and investments both in physical and human capital have a positive, albeit not always statistically significant, effect on growth. As in Judson and Orphanides (1999), Kalaitzidakis, Mamuneas and Stengos (2000) and Presbitero (2008), inflation volatility has a robust and negative effect on growth, suggesting that a stable macroeconomic environment is required to foster GDP growth. The quality of institutions and policies has a positive and significant effect on GROWTH, while trade openness does not significantly impact on economic growth, as suggested by Rodriguez and Rodrik (2001) (but in contrast to Frankel and Romer (1999), Yanikkaya (2003) and Wacziarg and Welch (2008), among others), especially once the effect of institutions is accounted for (Rodrik, Subramanian and Trebbi, 2004).

Coming to the key interest variable, column (1) shows that the ratio of total public debt to GDP has a negative and monotonic effect on economic growth. To test for the presence of a hump-shaped relationship as predicted by the Debt-Laffer hypothesis, in column (2) we impose a quadratic functional form. The coefficients on the linear and quadratic term are jointly significant and the test of the presence of an inverse U-shaped relationship proposed by Lind and Mehlum (2010) indicates that the Debt-Laffer curve is statistically significant with a maximum 
in correspondence of a ratio of total public debt over GDP of $27 \%(P U B L I C D E B T=3.36)^{13}$. Columns (3) and (4) report the results of a spline specification with one and two discontinuity points respectively, fixed at values of total public debt equal to 10 (T1) and 90 (T2) percent of GDP. The choice of the threshold is done considering the existing evidence and trying to find the model that best fits the data. The specification with one break at a debt-to-GDP ratio of 90 percent does not uncover any significant relationship, even if a slight increase in the threshold is consistent with a negative effect of public debt up to the 100 percent of GDP and to an irrelevance zone thereafter (Cordella, Ricci and Ruiz-Arranz, 2010) ${ }^{14}$. Imposing a second break in the spline specification does not affect the basic result on debt overhang and debt irrelevance, but uncovers a positive and strong effect of debt on growth as long as total public debt is below 10 percent of GDP. This positive correlation can explain the significance of the bell curve estimated in column (2). At the same time, however, it makes clear that imposing a quadratic specification can lead to misleading results, since only about two percent of sample observations fall below the $10 \%$ thresholds, while the $75 \%$ of observation are in the debt overhang zone (debt-to-GDP ratio between 10 and 90 percent) and the remaining $23 \%$ in the debt irrelevance zone (debt-to-GDP ratio above 90 percent). The impact of public debt is economically significant: in the short run, an increase of the public debt-to-GDP ratio by 30 percentage points, as happened in Turkey after the 2000-2001 financial crisis (Figure 2), costs 1.5 percentage points in economic growth.

Finally, in the last column we try to disentangle the source of the non-monotonicity allowing for an heterogeneous effect of PUBLIC DEBT on growth according to the country policy and institutional framework. Consistently with previous evidence on external debt (Arnone and Presbitero, 2010; Cordella, Ricci and Ruiz-Arranz, 2010), the empirical evidence supports the hypothesis that public debt is a growth constraint only in countries with good policies and strong institutions. The economic impact is slightly larger than the one estimated on the whole sample, since a 30 percent increase in the debt ratio is associated with a slowdown in output growth by 1.6 percent. By contrast, where policies and institutions are lousy, public debt is not correlated with GDP growth, which, instead, is likely to be constrained by macroeconomic instability and by the poor institutional framework. The coefficients on the CPIA dummy, in fact, show that the GDP growth rate of the average country with bad policies is half percentage point lower than the one of countries with good policies ${ }^{15}$. In support of this interpretation, which help explaining the non-linear effect of debt on growth (column 4), summary statistics show that total public debt is much lower where institutions and policies are strong $\left(C P I A_{\geq 3.5}=1\right)$ than where are weak $\left(C P I A_{\geq 3.5}=0\right)$, consistently a positive association between indebtedness and policy volatility (Malone, 2010) ${ }^{16}$.

In sum, as illustrated in Figure 3, the empirical results make clear that the hump-shaped

\footnotetext{
${ }^{13}$ Lind and Mehlum (2010) develop a test to avoid the misleading interpretation of a concave but monotone curve with an inverse U-shaped one, frequent when the turning point is too close to (or beyond) the end point of the data range. The procedure jointly tests whether the relationship between growth and debt is increasing at low values and decreasing at high values of PUBLIC DEBT within the sample, and it is implemented in Stata by the command UTEST.

${ }^{14}$ We prefer to leave the 90 percent threshold also for reason of comparability with the evidence documented by Reinhart and Rogoff (2010b) and by Kumar and Woo (2010). Estimating a spline specification with one discontinuity point in occurrence with a level of public debt equal to 10 percent of GDP uncover a positive (negative) correlation before (after) the threshold. These results are not shown (but are available upon request from the author) for reasons of space and because they are less informative than the reported model with two breaks.

${ }^{15}$ Summary statistics point out that countries with sound policies and institutions grow twice faster than the ones with a weak institutional setting.

${ }^{16}$ Specifically, total public debt is equal to 49 (66) percent of GDP in the average country with good (bad) institutions and policies and the difference is statistically significant.
} 
curve is driven by few observations. Considering the whole sample of countries and ignoring country-specific characteristics, actual data show that, apart from for very low values of total public debt, the basic relationship between PUBLIC DEBT and GROWTH is monotonic and negative up to a threshold (total public debt over GDP equal to $90 \%$, see the left-hand diagram) and irrelevant thereafter. This basic finding uncovers - and can be explained by - countryspecific characteristics: debt overhang is a primary constraint to investment and growth where the policy and institutional setting is stable, while total public debt does not matter for output growth as long as institutions are weak and macroeconomic policies bad (right-hand diagram). This result is consistent with a generalization of the Krugman's (1988) model of debt overhang in which a large eternal debt increases the incentive for incumbent government to "gamble for redemption" in order to avoid the high-probability job loss following an eventual default (Malone, 2010). Large debts go hand in hand with worsening macroeconomic policies and output and policy volatility, overshadowing the adverse effect of debt on economic growth.

Figure 3: Public debt and growth

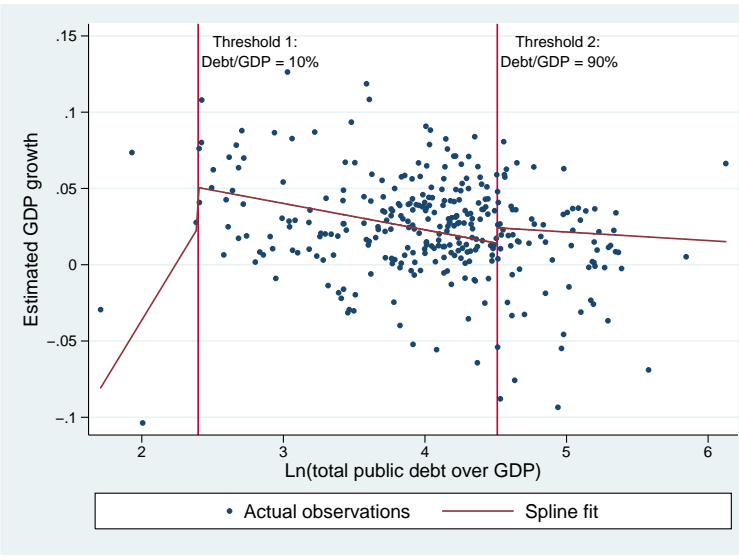

(a) Spline specification

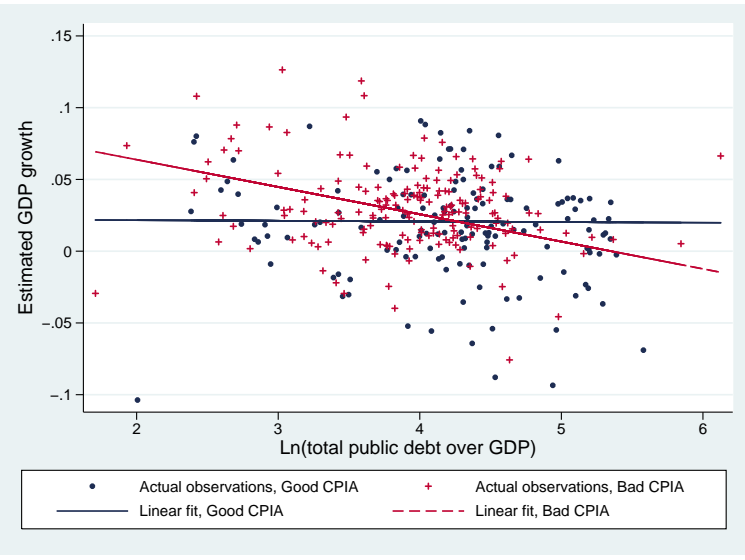

(b) Institutions and policies heterogeneity

Notes: Elaboration on estimates reported in Table 3, columns 4 (left panel) and 5 (right panel)

$B A D$ CPIA

(GOOD CPIA) refers to countries with an overall CPIA score lower than (equal to or greater than) 3.5.

\subsection{Robustness}

This section discusses some robustness exercises undertaken to validate the main findings of the paper. On the whole, results do not change with different definitions of the main variables (GROWTH and PUBLIC DEBT), with the inclusion of additional control variables and controlling for the problem of the proliferation of instruments in the GMM estimates (Roodman, $2009 a$ ). In Table 4 we address the endogeneity issue taking past values of public debt instead of the ones in the first year of the three-years period. While there is no more evidence of a basic linear and negative relationship between DEBT and GROWTH and also the quadratic specification looses significance, the main findings are confirmed. Public debt has a strong and negative impact on output growth for intermediate levels of indebtedness, while when public debt is above 90 percent of GDP, its effect on growth is not significant. Again, this non linearity can be easily accommodated taking into account country heterogeneity: column (5) confirms that, even considering past values of public debt, the overhang effect matters only for countries with good policies and institutions. As regards the coefficients on the control variables and the diagnostic tests, the values are broadly similar to the ones reported in Table 4, suggesting that 
the growth model is well specified.

In Table 5 we test the robustness of the main findings across changes in the set of control variables. The first four columns augment the preferred spline specification (Table 3, column 4), while the last four columns refer to the model allowing for the differentiated debt effect on growth according to the CPIA score (Table 3, column 5). Specifically, we include the population growth rate (POPULATION), a measure of private credit over GDP (CREDIT) and a dummy variable characterizing a regime as democratic $(D E M O C R A C Y)^{17}$; in columns 4 and 8 we also re-run the estimates measuring GDP (and its growth rate) at purchasing power parity $(G D P P P P)$. In all the specifications, the main conclusions drawn in Section 3.2 are confirmed, even if the additional controls do not generally show any robust correlation with output growth.

Finally, Table 6 presents the estimates obtained collapsing the instrument set, so that the number of instruments is significantly lower than the number of countries included in the sample. As in the previous regressions, the diagnostic tests support the model specification and the Hansen test of Over-Identifying Restrictions still validates the identification of the model and shows p-values lower than the ones reported in previous regressions. Even with a parsimonious instrument set, results are broadly confirmed and, if any, the negative debt effect on growth increases (column 4).

\section{Conclusions}

The evidence discussed in the paper on the relationship between total public debt and economic growth in low- and middle-income countries is consistent with the presence of a debt overhang and a debt irrelevance zones, as already found with respect to external debt (Cordella, Ricci and Ruiz-Arranz, 2010). The threshold separating the two zones is at a level of public debt equal to around 90 percent of GDP. This finding apparently contrasts to the widely cited evidence discussed by Reinhart and Rogoff (2010b) about grow slowdowns when public debt exceeds 90 percent of GDP. However, apart from differences in the methodological approach, the main reason explaining the antithetic results is likely to be the composition of the sample. In this vein, the evidence provided by this paper complements the one introduced by Reinhart and Rogoff (2010b), Caner, Grennes and Koehler-Geib (2010) and Kumar and Woo (2010): while they show that a debt burden above 90 percent is likely to hinder growth in advanced countries, we provide evidence that debt overhang in low and middle-income countries is a growth constraint also for lower levels of debt. This is consistent with the hypothesis of debt sustainability and debt management capacity increasing with income. Industrialized countries are better able than developing ones to borrow and use domestic and foreign financing in a productive way, without paying the costs in terms of disincentive to investment, capital flight, policy volatility and crowding out, that generally goes hand in hand with large debts. By contrast, in developing countries the negative consequences of debt overhang are likely to offset the possible benefits deriving from the availability of additional resources. The main reason for this opposite result is related to poor economic management and bad institutions, consistent with a "gambling for redemption" interpretation of the classical debt overhang model (Malone, 2010). In fact, the last piece of evidence discussed in the paper shows that country-specific factors affect the way in which debt affect the economy: as already shown with respect to external debt (Presbitero,

\footnotetext{
${ }^{17}$ We show the results obtained using the dummy variable proposed by Cheibub, Gandhi and Vreeland (2010), but results do not change adopting the continuous polity score calculated by the Polity IV project (Marshall, Gurr and Jaggers, 2010). Similarly, we controlled the robustness of our conclusions including a number of the other variables used in the growth literature, without finding significant changes in the debt effect on growth. Given the lack of informative power of this exercise, we choose to show only the results relative to the most widely used variables.
} 
2008; Cordella, Ricci and Ruiz-Arranz, 2010), also total public debt is a constraint for economic growth only in countries with sound institutions and stable macroeconomic policies. Thus, irrespective of the income level, poor institution and policies are likely to be the first-order constraint to growth. Where and when the institutional framework is sound, public debt has real effects on the economy: according to Reinhart and Rogoff (2010b) and Caner, Grennes and Koehler-Geib (2010), in industrialized countries debt overhang emerges as long as debt is particularly high - at least above 77 percent -, while the evidence discussed in the paper suggests that in developing countries, where institutions and macroeconomic policies are less strong, debt overhang is effective for an intermediate level of indebtedness. In addition, where debt is larger, macroeconomic policies are generally worse and more volatile and they overshadow the possible negative effects of debt on output growth, which become statistically not significant.

From a policy perspective, the results discussed in the paper can help shaping borrowing and debt relief policies. Specifically, the presence of a negative effect of total public debt on economic growth in developing countries has to be taken into consideration and requires a shift from a paradigm based almost exclusively on external debt to a new one based on both domestic and external debt, as recently recognized also by the IMF and the World Bank. Furthermore, as regard debt relief, it should be based on the amount of the stock of total public debt and it should be targeted only to countries with sound institutions, since only there public debt is likely to be a binding constraint to growth. If the eligibility criteria are measurable, realistic and public ex-ante, conditional debt relief would be not only economically efficient - maximizing the benefits of debt reduction in times of shrinking aid budgets -, but it will also provide the right incentives, working as an incentive-based "pull" mechanism to improve policy and institutional framework.

\section{References}

Abbas, Ali S. M. and Jakob E. Christensen. 2010. "The Role of Domestic Debt Markets in Economic Growth: An Empirical Investigation for Low-Income Countries and Emerging Markets." IMF Staff Papers 57(1):209-255.

Acemoglu, Daron and James A. Robinson. 2010. "The Role of Institutions in Growth and Development." Review of Economics and Institutions 1(2):Article 1.

Alesina, Alberto, Arnaud Devleeschauwer, William Easterly, Sergio Kurlat and Romain Wacziarg. 2003. "Fractionalization." Journal of Economic Growth 8(2):155-94.

Alesina, Alberto and Eliana La Ferrara. 2005. "Ethnic Diversity and Economic Performance." Journal of Economic Literature 43(3):762-800.

Alesina, Alberto and Guido Tabellini. 1989. "External debt, capital flight and political risk." Journal of International Economics 27(3-4):199-220.

Arellano, Manuel and Stephen Bond. 1991. "Some Tests of Specification for Panel Data: Monte Carlo Evidence and an Application to Employment Equations." Review of Economic Studies 58(2):277-97.

Arnone, Marco and Andrea F. Presbitero. 2010. Debt Relief Initiatives - Policy Design and Outcomes. Global Finance Farnham: Ashgate.

Arslanalp, Serkan and Peter Blair Henry. 2006. "Policy Watch: Debt Relief." Journal of Economic Perspectives 20(1):207-220. 
Arteta, Carlos, Barry Eichengreen and Charles Wyplosz. 2003. When does capital account liberalization help more than it hurts? In Economic policy in the international economy: Essays in honor of Assaf Razin, ed. Elhanan Helpman and Efraim Sadka. Cambridge: Cambridge University Press chapter 7, pp. 177-206.

Asiedu, Elizabeth. 2003. "Debt relief and institutional reform: a focus on Heavily Indebted Poor Countries." The Quarterly Review of Economics and Finance 43(4):614-626.

Blavy, Rodolphe. 2006. Public Debt and Productivity: The Difficult Quest for Growth in Jamaica. IMF Working Papers 06/235 International Monetary Fund.

Blundell, Richard and Stephen Bond. 1998. "Initial conditions and moment restrictions in dynamic panel data models." Journal of Econometrics 87(1):115-143.

Caner, Mehmet, Thomas Grennes and Fritzi Koehler-Geib. 2010. Finding the tipping point when sovereign debt turns bad. Policy Research Working Paper Series 5391 The World Bank.

Catini, Giulia, Ugo Panizza and Carol Saade. 2010. "Macro Data 4 Stata." http://sites.google.com/site/md4stata/.

Cecchetti, Stephen, Madhusudan Mohanty and Fabrizio Zampolli. 2010. The future of public debt: prospects and implications. BIS Working Papers 300 Bank for International Settlements.

Cerra, Valerie, Meenakshi Rishi and Sweta C. Saxena. 2008. "Robbing the Riches: Capital Flight, Institutions and Debt." Journal of Development Studies 44(8):1190-1213.

Cheibub, José, Jennifer Gandhi and James Vreeland. 2010. "Democracy and dictatorship revisited." Public Choice 143(1):67-101.

Christensen, Jakob. 2005. "Special Data Section Domestic Debt Markets in Sub-Saharan Africa." IMF Staff Papers 52(3):7.

Cline, William R. 2010. Financial Globalization, Economic Growth, and the Crisis of 2007-09. Washington D.C.: Peterson Institute for International Economics.

Cohen, Daniel. 1993. "Low Investment and Large LDC Debt in the 1980's." American Economic Review 83(3):437-49.

Cordella, Tito, Luca Antonio Ricci and Marta Ruiz-Arranz. 2010. "Debt Overhang or Debt Irrelevance?" IMF Staff Papers 57(1):1-24.

Dessy, Sylvain E. and Desire Vencatachellum. 2007. "Debt Relief and Social Services Expenditure: The African Experience, 1989-2003." African Development Review 19(1):200-216.

Durlauf, Steven N., Paul A. Johnson and Jonathan R.W. Temple. 2005. Growth Econometrics. In Handbook of Economic Growth, ed. Philippe Aghion and Steven Durlauf. Vol. 1 of Handbook of Economic Growth Elsevier chapter 8, pp. 555-677.

Fosu, Augustin Kwasi. 1996. "The Impact of External Debt on Economic Growth in Sub-Saharan Africa." Journal of Development Economics 21(1):93-117.

Frankel, Jeffrey A. and David Romer. 1999. "Does Trade Cause Growth?" American Economic Review 89(3):379-399.

Green, Joshua and Delano Villanueva. 1991. "Private Investment in Developing Countries: An Empirical Analysis." IMF Staff Papers 38(1):33-58. 
Hansen, Bruce E. 2000. "Sample Splitting and Threshold Estimation." Econometrica 68(3):575604.

Hanson, James A. 2007. The growth in government domestic debt : changing burdens and risks. Policy Research Working Paper Series 4348 The World Bank.

Harrabi, Sana, Lobna Bousrih and Mohammed Salisu. 2007. "Debt Relief and Credit to the Private Sector in African Countries." African Development Review 19(3):469-480.

Hauk, William and Romain Wacziarg. 2009. "A Monte Carlo study of growth regressions." Journal of Economic Growth 14(2):103-147.

Hodrick, Robert J and Edward C Prescott. 1997. "Postwar U.S. Business Cycles: An Empirical Investigation." Journal of Money, Credit and Banking 29(1):1-16.

International Development Association. 2007. Country Policy and Institutional Assessment 2007 Assessment Questionnaire. Technical report The World Bank.

International Monetary Fund. 2010. World Ecoomic Outlook - Rebalancing Growth. International Monetary Fund.

Judson, Ruth and Athanasios Orphanides. 1999. "Inflation, Volatility and Growth." International Finance 2(1):117-38.

Kalaitzidakis, Pantelis, Theofanis P. Mamuneas, Andreas Savvides and Thanasis Stengos. 2001. "Measures of Human Capital and Nonlinearities in Economic Growth." Journal of Economic Growth 6(3):229-54.

Kalaitzidakis, Pantelis, Theofanis P. Mamuneas and Thanasis Stengos. 2000. "A non-linear sensitivity analysis of cross-country growth regressions." Canadian Journal of Economics 33(3):604-617.

Kose, M. Ayhan, Eswar S. Prasad and Ashley D. Taylor. 2010. "Thresholds in the process of international financial integration." Journal of International Money and Finance forthcoming.

Kose, M. Ayhan, Eswar S. Prasad, Kenneth S. Rogoff and Shang-Jin Wei. 2009. "Financial Globalization: A Reappraisal." IMF Staff Papers 56(1):8-62.

Krugman, Paul. 1988. "Financing vs. forgiving a debt overhang." Journal of Development Economics 29(3):253-268.

Kumar, Manmohan S. and Jaejoon Woo. 2010. Public Debt and Growth. IMF Working Papers 10/174 International Monetary Fund.

La Porta, Rafael, Florencio Lopez-de Silanes, Andrei Shleifer and Robert W. Vishny. 1997. "Legal Determinants of External Finance." Journal of Finance 52(3):1131-50.

La Porta, Rafael, Florencio Lopez-de Silanes, Andrei Shleifer and Robert W. Vishny. 1998. "Law and Finance." Journal of Political Economy 106(6):1113-1155.

La Porta, Rafael, Florencio Lopez-de Silanes, Andrei Shleifer and Robert W. Vishny. 2008. "The Economic Consequences of Legal Origins." Journal of Economic Literature 46(2):285-332.

Levine, Ross and David Renelt. 1992. "A Sensitivity Analysis of Cross-Country Growth Regressions." American Economic Review 82(4):942-63. 
Lind, Jo Thori and Halvor Mehlum. 2010. "With or Without U? The Appropriate Test for a U-Shaped Relationship." Oxford Bulletin of Economics and Statistics 72(1):109-118.

Malone, Samuel W. 2010. "Sovereign Indebtedness, Default and Gambling for Redemption." Oxford Economic Papers forthcoming.

Mankiw, N Gregory, David Romer and David N Weil. 1992. "A Contribution to the Empirics of Economic Growth." The Quarterly Journal of Economics 107(2):407-37.

Marsh, Lawrence C. and David R Cormier. 2002. Spline Regression Models. Quantitative Applications in the Social Sciences Thousand Oaks: Sage Publications.

Marshall, Monty G., Ted Robert Gurr and Keith Jaggers. 2010. POLITY IV Project: Political Regime Characteristics and Transitions, 1800-2009. Center for Systemic Peace.

Panizza, Ugo. 2008. Domestic And External Public Debt In Developing Countries. UNCTAD Discussion Papers 188 United Nations Conference on Trade and Development.

Panizza, Ugo and Eduardo Levy Yeyati. 2010. "The elusive costs of sovereign defaults." Journal of Development Economics forthcoming.

Presbitero, Andrea F. 2008. "The Debt-Growth Nexus in Poor Countries: A Reassessment." Economics: The Open-Access, Open-Assessment E-Journal 2(30).

Presbitero, Andrea F. 2010. "The Debt-Growth Nexus in Jamaica." Università Politecnica delle Marche.

Ravn, Morten O. and Harald Uhlig. 2002. "On adjusting the Hodrick-Prescott filter for the frequency of observations." The Review of Economics and Statistics 84(2):371-375.

Reinhart, Carmen M. and Kenneth S. Rogoff. 2009. This Time is Different. Princeton, New Jersey: Princeton University Press.

Reinhart, Carmen M. and Kenneth S. Rogoff. 2010a. Debt and Growth Revisited. MPRA Paper 24376 University Library of Munich, Germany http://ideas.repec.org/p/pra/mprapa/24376.html: .

Reinhart, Carmen M. and Kenneth S. Rogoff. 2010b. "Growth in a Time of Debt." American Economic Review 100(2):573-78.

Rodriguez, Francisco and Dani Rodrik. 2001. Trade Policy and Economic Growth: A Skeptic's Guide to the Cross-National Evidence. In NBER Macroeconomics Annual 2000, Volume 15. NBER Chapters National Bureau of Economic Research, Inc pp. 261-338.

Rodrik, Dani, Arvind Subramanian and Francesco Trebbi. 2004. "Institutions Rule: The Primacy of Institutions Over Geography and Integration in Economic Development." Journal of Economic Growth 9(2):131-165.

Roodman, David. 2009a. "How to do xtabond2: An introduction to difference and system GMM in Stata." Stata Journal 9(1):86-136.

Roodman, David. 2009b. "A Note on the Theme of Too Many Instruments." Oxford Bulletin of Economics and Statistics 71(1):135-158. 
Sachs, Jeffrey D. 1989. The Debt Overhang of Developing Countries. In Debt, Stabilization and Development, ed. Guillermo A. Calvo, Ronald Findlay, Pentti Kouri and Jorge Braga de Macedo. Oxford: Basil Blackwell.

Savvides, Andreas. 1992. "Investment Slowdown in Developing Countries during the 1980s: Debt Overhang or Foreign Capital Inflows?" Kyklos 45(3):363-78.

Serven, Luis. 1997. "Irreversibility, Uncertainty and Private Investment: Analytical Issues and Some Lessons for Africa." Journal of African Economies 6(3):229-68.

Singh, Anoop. 2006. Macroeconomic Volatility: The Policy Lessons from Latin America. IMF Working Papers 06/166 International Monetary Fund.

Solow, Robert M. 1956. "A Contribution to the Theory of Economic Growth." The Quarterly Journal of Economics 70(1):65-94.

Wacziarg, Romain and Karen Horn Welch. 2008. "Trade Liberalization and Growth: New Evidence." World Bank Economic Review 22(2):187-231.

Windmeijer, Frank. 2005. "A finite sample correction for the variance of linear efficient two-step GMM estimators." Journal of Econometrics 126(1):25-51.

Yanikkaya, Halit. 2003. "Trade openness and economic growth: a cross-country empirical investigation." Journal of Development Economics 72(1):57-89. 


\section{A Tables}

Table 1: Sample of 92 low- and middle-income countries

\begin{tabular}{|c|c|c|c|c|c|c|c|}
\hline Code & Country & Income & Region & Code & Country & Income & Region \\
\hline ALB & Albania & LMIC & ECA & LKA & Sri Lanka & LMIC & SA \\
\hline ARG & Argentina & UMIC & LAC & LSO & Lesotho & LMIC & SSA \\
\hline ARM & Armenia & LMIC & ECA & LTU & Lithuania & UMIC & ECA \\
\hline BDI & Burundi & LIC & SSA & LVA & Latvia & UMIC & ECA \\
\hline BGR & Bulgaria & UMIC & ECA & MAR & Morocco & LMIC & MENA \\
\hline BLR & Belarus & UMIC & ECA & MDA & Moldova & LMIC & ECA \\
\hline BLZ & Belize & LMIC & $\mathrm{LAC}$ & MEX & Mexico & UMIC & LAC \\
\hline BOL & Bolivia & LMIC & $\mathrm{LAC}$ & MNG & Mongolia & LMIC & EAP \\
\hline BRA & Brazil & UMIC & LAC & MOZ & Mozambique & LIC & SSA \\
\hline BTN & Bhutan & LMIC & SA & MRT & Mauritania & LIC & SSA \\
\hline BWA & Botswana & UMIC & SSA & MUS & Mauritius & UMIC & SSA \\
\hline CHL & Chile & UMIC & $\mathrm{LAC}$ & MWI & Malawi & LIC & SSA \\
\hline CHN & China & LMIC & EAP & MYS & Malaysia & UMIC & EAP \\
\hline CIV & Cote d'Ivoire & LMIC & SSA & NAM & Namibia & UMIC & SSA \\
\hline CMR & Cameroon & LMIC & SSA & NIC & Nicaragua & LMIC & $\mathrm{LAC}$ \\
\hline COD & Congo, DR & LIC & SSA & NPL & Nepal & LIC & SA \\
\hline COL & Colombia & UMIC & LAC & PAK & Pakistan & LMIC & SA \\
\hline CPV & Cape Verde & LMIC & SSA & PAN & Panama & UMIC & LAC \\
\hline CRI & Costa Rica & UMIC & LAC & PER & Peru & UMIC & LAC \\
\hline DJI & Djibouti & LMIC & MENA & PHL & Philippines & LMIC & EAP \\
\hline DOM & Dominican Rep. & UMIC & LAC & POL & Poland & UMIC & ECA \\
\hline DZA & Algeria & UMIC & MENA & PRY & Paraguay & LMIC & $\mathrm{LAC}$ \\
\hline $\mathrm{ECU}$ & Ecuador & LMIC & LAC & ROU & Romania & UMIC & ECA \\
\hline EGY & Egypt & LMIC & MENA & RUS & Russian Federation & UMIC & ECA \\
\hline ERI & Eritrea & LIC & SSA & RWA & Rwanda & LIC & SSA \\
\hline ETH & Ethiopia & LIC & SSA & SDN & Sudan & LMIC & SSA \\
\hline FJI & Fiji & UMIC & EAP & SEN & Senegal & LIC & SSA \\
\hline GAB & Gabon & UMIC & SSA & SLE & Sierra Leone & LIC & SSA \\
\hline GEO & Georgia & LMIC & ECA & SLV & El Salvador & LMIC & LAC \\
\hline GHA & Ghana & LIC & SSA & SWZ & Swaziland & LMIC & SSA \\
\hline GIN & Guinea & LIC & SSA & TCD & Chad & LIC & SSA \\
\hline GMB & Gambia & LIC & SSA & THA & Thailand & LMIC & EAP \\
\hline GRD & Grenada & UMIC & LAC & TJK & Tajikistan & LIC & ECA \\
\hline GTM & Guatemala & LMIC & LAC & TON & Tonga & LMIC & EAP \\
\hline GUY & Guyana & LMIC & LAC & TUN & Tunisia & LMIC & MENA \\
\hline HND & Honduras & LMIC & LAC & TUR & Turkey & UMIC & ECA \\
\hline IDN & Indonesia & LMIC & EAP & UGA & Uganda & LIC & SSA \\
\hline IND & India & LMIC & SA & UKR & Ukraine & LMIC & ECA \\
\hline JOR & Jordan & LMIC & MENA & URY & Uruguay & UMIC & LAC \\
\hline KAZ & Kazakhstan & UMIC & ECA & UZB & Uzbekistan & LIC & ECA \\
\hline KEN & Kenya & LIC & SSA & $\mathrm{VCT}$ & St. Vincent \& Grenadines & UMIC & LAC \\
\hline KGZ & Kyrgyz Rep. & LIC & ECA & VEN & Venezuela & UMIC & LAC \\
\hline KHM & Cambodia & LIC & EAP & VUT & Vanuatu & LMIC & EAP \\
\hline LAO & Lao PDR & LIC & EAP & ZAF & South Africa & UMIC & SSA \\
\hline LBN & Lebanon & UMIC & MENA & ZMB & Zambia & LIC & SSA \\
\hline LCA & St. Lucia & UMIC & LAC & ZWE & Zimbabwe & LIC & SSA \\
\hline
\end{tabular}

Notes: The 3-letters country code, and the income and geographic classification is taken from the World Bank (see the website at: http://go.worldbank.org/K2CKM78CC0). ECA: Europe \& Central Asia; SSA: Sub-Saharan Africa; SA: South Asia; EAP: East Asia \& Pacific; LAC: Latin America \& Caribbean; MENA: North Africa \& Middle East. 
Table 2: Variables: description, sources and summary statistics

\begin{tabular}{|c|c|c|c|}
\hline VARIABLE & DESCRIPTION & MEAN & St. Dev. \\
\hline GROWTH & $\begin{array}{l}\text { Annual per capita GDP growth calculated ad log-difference of } \\
G D P \text {. Source: WDI. }\end{array}$ & 0.024 & 0.033 \\
\hline$G D P$ & $\begin{array}{l}\text { Logarithm of per capita GDP at constant US dollar. Source: } \\
\text { WDI. }\end{array}$ & 6.940 & 1.089 \\
\hline INVESTMENT & Logarithm of gross capital formation (\% GDP). Source: WDI. & 3.083 & 0.354 \\
\hline INFLATION & $\begin{array}{l}\text { Logarithm of } 1 \text { plus the standard deviation of inflation over the } \\
\text { three-years window, measured by the GDP deflator (annual \%). } \\
\text { Source: WDI. }\end{array}$ & 1.613 & 1.120 \\
\hline $\begin{array}{l}H U M A N \\
C A P I T A L\end{array}$ & $\begin{array}{l}\text { Logarithm of the primary gross school enrollment (\%). Source: } \\
\text { WDI. }\end{array}$ & 4.585 & 0.232 \\
\hline$O P E N N E S S$ & $\begin{array}{l}\text { Logarithm of the sum of exports and imports of goods and } \\
\text { services (\% GDP). Source: WDI. }\end{array}$ & 4.266 & 0.503 \\
\hline$C P I A$ & $\begin{array}{l}\text { Country Policy and Institutional Assessment overall score (or } \\
\text { IDA resource allocation index). Source: WDI and internal } \\
\text { (confidential) data set. }\end{array}$ & 3.568 & 0.627 \\
\hline PUBLIC DEBT & $\begin{array}{l}\text { Logarithm of total public debt over filtered GDP measured in the } \\
\text { first year of the three-years window. Source: Panizza (2008). }\end{array}$ & 4.045 & 0.717 \\
\hline$L E G A L O R I G I N S$ & $\begin{array}{l}\text { Categorical variable identifying the country's legal origin of the } \\
\text { Company Law or Commercial code. Source: La Porta et al. } \\
(1997,1998) \text {. }\end{array}$ & \multicolumn{2}{|c|}{ Not applicable } \\
\hline ETHNIC & Index of of ethnic fractionalization. Source: Alesina et al. (2003). & 0.482 & 0.229 \\
\hline \multicolumn{4}{|c|}{ FRACTIONALIZATION } \\
\hline POPULATION & Population growth (annual \%). Source: WDI. & 1.596 & 1.132 \\
\hline CREDIT & $\begin{array}{l}\text { Domestic credit provided by banking sector over GDP. Source: } \\
\text { WDI. }\end{array}$ & 0.456 & 0.410 \\
\hline$D E M O C R A C Y$ & $\begin{array}{l}\text { Dummy variable equal to one for countries with a democratic } \\
\text { regime. Source: Cheibub, Gandhi and Vreeland (2010) }\end{array}$ & 0.514 & 0.495 \\
\hline GROWTH PPP & $\begin{array}{l}\text { Annual per capita GDP growth calculated ad log-difference of } \\
G D P \text { PPP. Source: WDI. }\end{array}$ & 0.024 & 0.032 \\
\hline$G D P P P P$ & $\begin{array}{l}\text { Logarithm of per capita GDP at constant } 2005 \text { international } \\
\text { purchasing power parity. Source: WDI. }\end{array}$ & 7.995 & 0.924 \\
\hline
\end{tabular}

Notes: Statistics are calculated on the sample of 92 low- and middle-income countries (see Table 1), apart from variables for which there are missing values. All variables are non-overlapping three-years averages, apart from $P U B L I C D E B T$ which is taken at the first year of the five-years period. 
Table 3: Total public debt and economic growth: base model

\begin{tabular}{|c|c|c|c|c|c|}
\hline Dep. Var.: GROWTH & 1 & 2 & 3 & 4 & 5 \\
\hline$G D P_{t-1}$ & $\begin{array}{c}-0.020^{* * *} \\
{[0.000]}\end{array}$ & $\begin{array}{c}-0.017^{* * *} \\
{[0.000]}\end{array}$ & $\begin{array}{c}-0.017^{* * *} \\
{[0.000]}\end{array}$ & $\begin{array}{c}-0.018^{* * *} \\
{[0.000]}\end{array}$ & $\begin{array}{c}-0.018^{* * *} \\
{[0.000]}\end{array}$ \\
\hline INVESTMENT & $\begin{array}{c}0.021^{* *} \\
{[0.022]}\end{array}$ & $\begin{array}{c}0.026^{* *} \\
{[0.041]}\end{array}$ & $\begin{array}{c}0.021^{* *} \\
{[0.036]}\end{array}$ & $\begin{array}{c}0.015 \\
{[0.135]}\end{array}$ & $\begin{array}{c}0.027^{* * *} \\
{[0.002]}\end{array}$ \\
\hline INFLATION & $\begin{array}{c}-0.007^{* *} \\
{[0.033]}\end{array}$ & $\begin{array}{c}-0.007^{* * *} \\
{[0.009]}\end{array}$ & $\begin{array}{c}-0.007^{* *} \\
{[0.014]}\end{array}$ & $\begin{array}{c}-0.007^{* * *} \\
{[0.000]}\end{array}$ & $\begin{array}{c}-0.011^{* * *} \\
{[0.001]}\end{array}$ \\
\hline$H U M A N C A P I T A L$ & $\begin{array}{c}0.047^{* * *} * \\
{[0.007]}\end{array}$ & $\begin{array}{l}0.033^{*} \\
{[0.088]}\end{array}$ & $\begin{array}{c}0.037 \\
{[0.132]}\end{array}$ & $\begin{array}{c}0.025 \\
{[0.146]}\end{array}$ & $\begin{array}{l}0.040^{*} \\
{[0.092]}\end{array}$ \\
\hline$O P E N N E S S$ & $\begin{array}{l}-0.002 \\
{[0.707]}\end{array}$ & $\begin{array}{l}-0.001 \\
{[0.897]}\end{array}$ & $\begin{array}{l}-0.004 \\
{[0.623]}\end{array}$ & $\begin{array}{c}0.000 \\
{[0.964]}\end{array}$ & $\begin{array}{l}-0.002 \\
{[0.679]}\end{array}$ \\
\hline$C P I A$ & $\begin{array}{c}0.015^{* * *} \\
{[0.003]}\end{array}$ & $\begin{array}{c}0.013^{* *} \\
{[0.017]}\end{array}$ & $\begin{array}{c}0.014^{* * *} \\
{[0.006]}\end{array}$ & $\begin{array}{c}0.018^{* * *} \\
{[0.000]}\end{array}$ & \\
\hline$P U B L I C D E B T$ & $\begin{array}{c}-0.008^{*} \\
{[0.098]}\end{array}$ & $\begin{array}{c}0.055 \\
{[0.104]}\end{array}$ & & & $\begin{array}{c}0.000 \\
{[0.950]}\end{array}$ \\
\hline$P U B L I C D E B T^{2}$ & & $\begin{array}{c}-0.008^{*} \\
{[0.073]}\end{array}$ & & & \\
\hline$P U B L I C D E B T_{<T 1}$ & & & $\begin{array}{l}-0.008 \\
{[0.129]}\end{array}$ & $\begin{array}{c}0.153^{* * *} \\
{[0.000]}\end{array}$ & \\
\hline$P U B L I C D E B T_{>T 1}$ & & & $\begin{array}{l}-0.009 \\
{[0.503]}\end{array}$ & & \\
\hline$P U B L I C D E B T_{T 1-T 2}$ & & & & $\begin{array}{c}-0.017^{* * *} \\
{[0.005]}\end{array}$ & \\
\hline$P U B L I C D E B T_{>T 2}$ & & & & $\begin{array}{l}-0.006 \\
{[0.659]}\end{array}$ & \\
\hline$C P I A_{\geq 3.5}(0,1)$ & & & & & $\begin{array}{c}0.079^{* *} \\
{[0.013]}\end{array}$ \\
\hline$C P I A_{\geq 3.5} \times P U B L I C D E B T$ & & & & & $\begin{array}{c}-0.019 * * \\
{[0.018]}\end{array}$ \\
\hline Observations & 320 & 320 & 320 & 320 & 320 \\
\hline Countries & 92 & 92 & 92 & 92 & 92 \\
\hline $\operatorname{AR}(1)$ & 0.003 & 0.003 & 0.003 & 0.008 & 0.003 \\
\hline $\operatorname{AR}(2)$ & 0.818 & 0.801 & 0.929 & 0.81 & 0.791 \\
\hline Hansen OIR & 0.711 & 0.932 & 0.919 & 0.998 & 0.774 \\
\hline
\end{tabular}

Notes: The table reports regression coefficients and, in brackets, the associated robust standard errors. ${ }^{*}$ significant at $10 \%$; ** significant at 5\%; ${ }^{* *}$ significant at 1\%. The model is estimated by Two-Step System GMM, using Stata 11 SE package with XTABOND2 command. As instruments, we use (t-1) and ( $\mathrm{t}-2)$ lagged values of endogenous variables. Six geographic and five time dummies (included in the regressions but not shown for reasons of space) are taken as strictly exogenous regressors. LEGAL ORIGINS and ETHNIC FRACTIONALIZATION are included as additional instruments. $P U B L I C D E B T$ is taken in the first year of the three-years period. In the spline specification (columns 3 and 4), the discontinuity points $T 1$ and $T 2$ are set, respectively, at a level of public debt equal to 10 and 90 percent of GDP (PUBLIC DEBT equal to 2.398 and 4.511). As diagnostic, the table reports the p-values of the Hansen test for overidentifying restrictions (OIR, the null is the validity of the instrument set) and of the Arellano and Bond autocorrelation tests of first and second order $(\operatorname{AR}(1)$ and $\operatorname{AR}(2)$, the null is no autocorrelation). 
Table 4: Total public debt and economic growth: past debt ratios

\begin{tabular}{|c|c|c|c|c|c|}
\hline Dep. Var.: GROWTH & 1 & 2 & 3 & 4 & 5 \\
\hline$G D P_{t-1}$ & $\begin{array}{c}-0.018^{* * *} \\
{[0.000]}\end{array}$ & $\begin{array}{c}-0.015^{* * *} \\
{[0.002]}\end{array}$ & $\begin{array}{c}-0.017^{* * *} \\
{[0.001]}\end{array}$ & $\begin{array}{c}-0.018^{* * *} \\
{[0.000]}\end{array}$ & $\begin{array}{c}-0.017^{* * *} \\
{[0.000]}\end{array}$ \\
\hline INVESTMENT & $\begin{array}{c}0.036^{* * *} \\
{[0.001]}\end{array}$ & $\begin{array}{c}0.040^{* * *} \\
{[0.001]}\end{array}$ & $\begin{array}{c}0.032^{* *} \\
{[0.014]}\end{array}$ & $\begin{array}{c}0.026^{* *} \\
{[0.032]}\end{array}$ & $\begin{array}{c}0.037^{* * *} \\
{[0.000]}\end{array}$ \\
\hline INFLATION & $\begin{array}{c}-0.009^{* * *} \\
{[0.005]}\end{array}$ & $\begin{array}{c}-0.008^{* *} \\
{[0.016]}\end{array}$ & $\begin{array}{c}-0.009^{* *} \\
{[0.012]}\end{array}$ & $\begin{array}{c}-0.009 * * * \\
{[0.002]}\end{array}$ & $\begin{array}{c}-0.011^{* * *} \\
{[0.002]}\end{array}$ \\
\hline$H U M A N C A P I T A L$ & $\begin{array}{l}0.044^{*} \\
{[0.088]}\end{array}$ & $\begin{array}{c}0.029 \\
{[0.271]}\end{array}$ & $\begin{array}{l}0.041^{*} \\
{[0.093]}\end{array}$ & $\begin{array}{c}0.011 \\
{[0.614]}\end{array}$ & $\begin{array}{c}0.032 \\
{[0.132]}\end{array}$ \\
\hline OPENNESS & $\begin{array}{l}-0.007 \\
{[0.340]}\end{array}$ & $\begin{array}{l}-0.005 \\
{[0.619]}\end{array}$ & $\begin{array}{l}-0.010 \\
{[0.178]}\end{array}$ & $\begin{array}{l}-0.004 \\
{[0.569]}\end{array}$ & $\begin{array}{l}-0.007 \\
{[0.192]}\end{array}$ \\
\hline$C P I A$ & $\begin{array}{c}0.010 \\
{[0.147]}\end{array}$ & $\begin{array}{c}0.010 \\
{[0.103]}\end{array}$ & $\begin{array}{c}0.009 \\
{[0.161]}\end{array}$ & $\begin{array}{c}0.008 \\
{[0.209]}\end{array}$ & \\
\hline$P U B L I C D E B T_{t-1}$ & $\begin{array}{l}-0.003 \\
{[0.530]}\end{array}$ & $\begin{array}{c}0.040 \\
{[0.262]}\end{array}$ & & & $\begin{array}{c}0.004 \\
{[0.566]}\end{array}$ \\
\hline$P U B L I C D E B T_{t-1}^{2}$ & & $\begin{array}{l}-0.005 \\
{[0.270]}\end{array}$ & & & \\
\hline$P U B L I C D E B T_{(t-1),<T 1}$ & & & $\begin{array}{l}-0.003 \\
{[0.725]}\end{array}$ & $\begin{array}{c}0.201^{* *} \\
{[0.015]}\end{array}$ & \\
\hline$P U B L I C D E B T_{(t-1),>T 1}$ & & & $\begin{array}{l}-0.002 \\
{[0.884]}\end{array}$ & & \\
\hline$P U B L I C D E B T_{(t-1), T 1-T 2}$ & & & & $\begin{array}{r}-0.018^{*} \\
{[0.064]}\end{array}$ & \\
\hline$P U B L I C D E B T_{(t-1),>T 2}$ & & & & $\begin{array}{l}-0.003 \\
{[0.824]}\end{array}$ & \\
\hline$C P I A_{\geq 3.5}(0,1)$ & & & & & $\begin{array}{c}0.072^{* *} \\
{[0.032]}\end{array}$ \\
\hline$C P I A_{\geq 3.5} \times P U B L I C D E B T_{t-1}$ & & & & & $\begin{array}{c}-0.017^{* *} \\
{[0.037]}\end{array}$ \\
\hline Observations & 324 & 324 & 324 & 324 & 324 \\
\hline Countries & 92 & 92 & 92 & 92 & 92 \\
\hline $\operatorname{AR}(1)$ & 0.002 & 0.001 & 0.001 & 0.003 & 0.001 \\
\hline $\operatorname{AR}(2)$ & 0.979 & 0.836 & 0.988 & 0.201 & 0.658 \\
\hline Hansen OIR & 0.626 & 0.839 & 0.865 & 0.978 & 0.773 \\
\hline
\end{tabular}

Notes: The table reports regression coefficients and, in brackets, the associated robust standard errors. ${ }^{*}$ significant at $10 \%$; ** significant at 5\%; ${ }^{* *}$ significant at 1\%. The model is estimated by Two-Step System GMM, using Stata 11 SE package with XTABOND2 command. As instruments, we use (t-1) and ( $\mathrm{t}-2)$ lagged values of endogenous variables. Six geographic and five time dummies (included in the regressions but not shown for reasons of space) are taken as strictly exogenous regressors. LEGAL ORIGINS and ETHNIC FRACTIONALIZATION are included as additional instruments. $P U B L I C D E B T_{t-1}$ is taken in the previous the three-years period. In the spline specification (columns 3 and 4), the discontinuity points $T 1$ and $T 2$ are set, respectively, at a level of public debt equal to 10 and 90 percent of GDP (PUBLIC DEBT equal to 2.398 and 4.511). As diagnostic, the table reports the p-values of the Hansen test for overidentifying restrictions (OIR, the null is the validity of the instrument set) and of the Arellano and Bond autocorrelation tests of first and second order $(\operatorname{AR}(1)$ and $\operatorname{AR}(2)$, the null is no autocorrelation). 


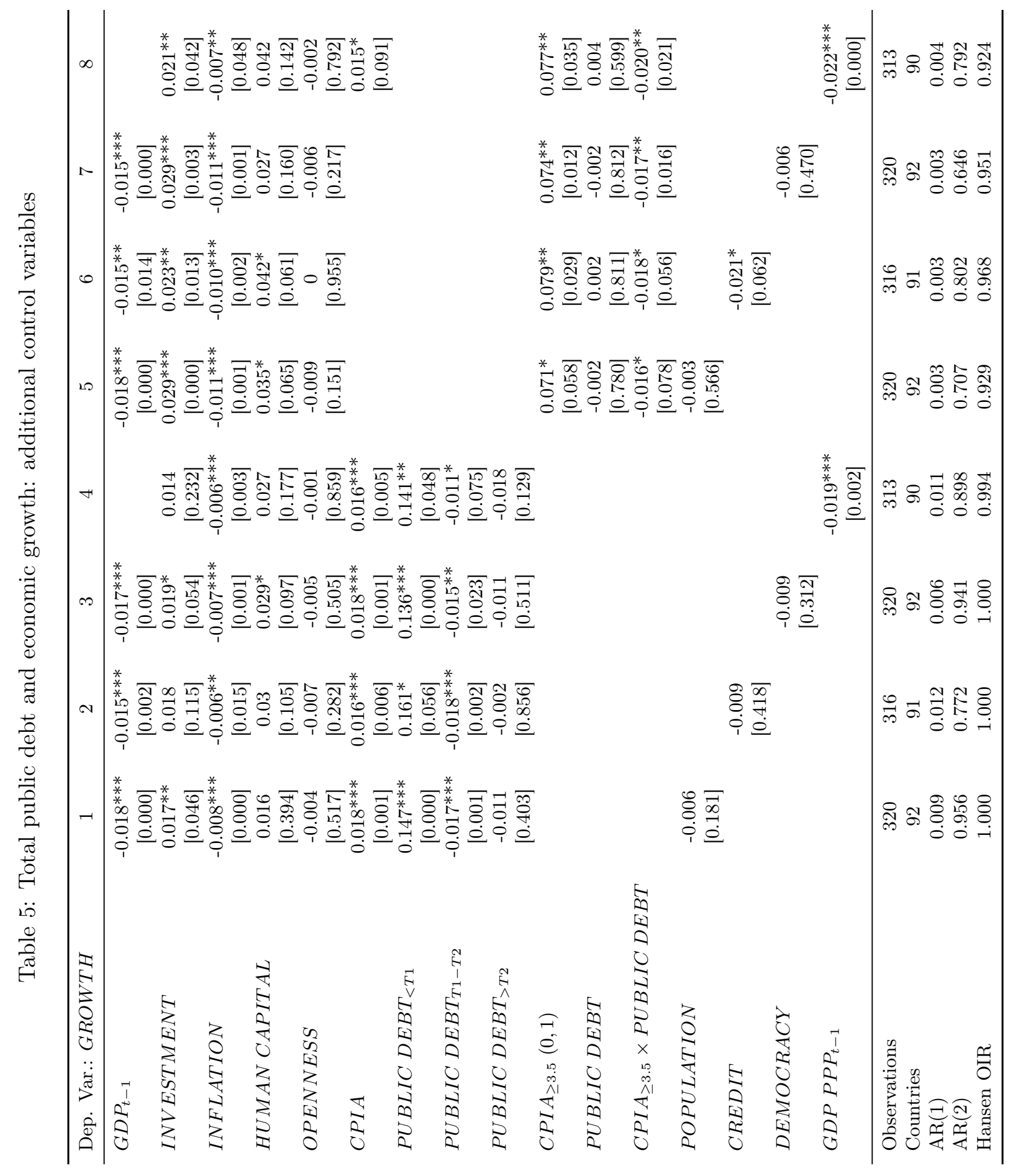

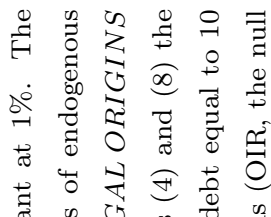

$\begin{array}{lll} & 0 \\ 0\end{array}$

药

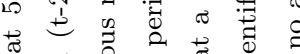

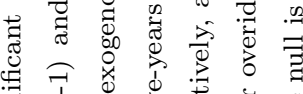

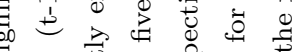

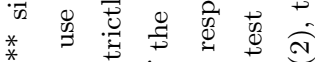

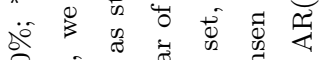

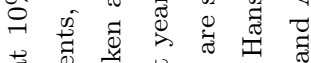

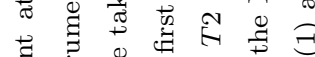

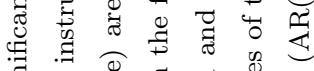

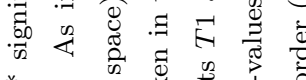
* 영

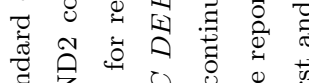

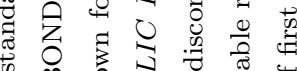

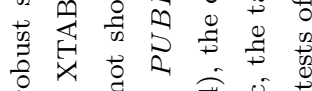

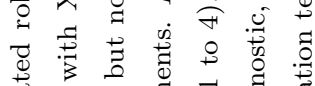

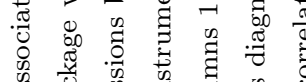

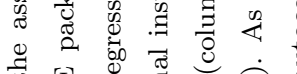
思要

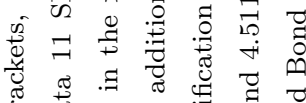

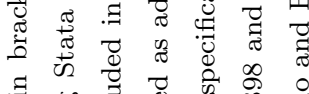

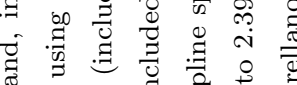
क 50

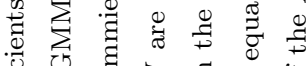
다의

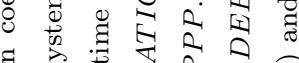
की कू कै च

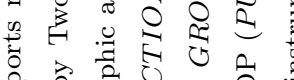

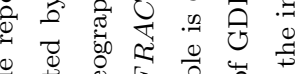
然

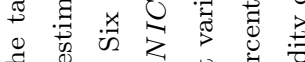

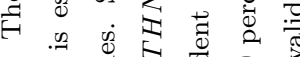

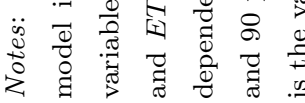


Table 6: Total public debt and economic growth: instruments collapse

\begin{tabular}{|c|c|c|c|c|c|}
\hline Dep. Var.: GROWTH & 1 & 2 & 3 & 4 & 5 \\
\hline$G D P_{t-1}$ & $\begin{array}{c}-0.031^{* * *} \\
{[0.000]}\end{array}$ & $\begin{array}{c}-0.032^{* * *} \\
{[0.000]}\end{array}$ & $\begin{array}{c}-0.030^{* * *} \\
{[0.000]}\end{array}$ & $\begin{array}{c}-0.027^{* * *} \\
{[0.000]}\end{array}$ & $\begin{array}{c}-0.020^{* * *} \\
{[0.000]}\end{array}$ \\
\hline INVESTMENT & $\begin{array}{c}0.007 \\
{[0.696]}\end{array}$ & $\begin{array}{c}0.018 \\
{[0.361]}\end{array}$ & $\begin{array}{c}0.018 \\
{[0.263]}\end{array}$ & $\begin{array}{c}0.014 \\
{[0.349]}\end{array}$ & $\begin{array}{c}0.029^{* * *} \\
{[0.005]}\end{array}$ \\
\hline INFLATION & $\begin{array}{c}-0.006^{*} \\
{[0.055]}\end{array}$ & $\begin{array}{c}-0.007^{*} \\
{[0.050]}\end{array}$ & $\begin{array}{c}-0.007^{* *} \\
{[0.033]}\end{array}$ & $\begin{array}{c}-0.007^{* *} \\
{[0.017]}\end{array}$ & $\begin{array}{c}-0.011^{* * *} \\
{[0.001]}\end{array}$ \\
\hline$H U M A N C A P I T A L$ & $\begin{array}{c}0.086^{* * *} \\
{[0.005]}\end{array}$ & $\begin{array}{l}0.056^{*} \\
{[0.081]}\end{array}$ & $\begin{array}{c}0.077^{* *} \\
{[0.038]}\end{array}$ & $\begin{array}{l}0.045^{*} \\
{[0.085]}\end{array}$ & $\begin{array}{c}0.038 \\
{[0.126]}\end{array}$ \\
\hline$O P E N N E S S$ & $\begin{array}{l}-0.014 \\
{[0.229]}\end{array}$ & $\begin{array}{l}-0.009 \\
{[0.538]}\end{array}$ & $\begin{array}{l}-0.016 \\
{[0.192]}\end{array}$ & $\begin{array}{l}-0.016 \\
{[0.215]}\end{array}$ & $\begin{array}{l}-0.005 \\
{[0.466]}\end{array}$ \\
\hline$C P I A$ & $\begin{array}{c}0.020^{* *} \\
{[0.020]}\end{array}$ & $\begin{array}{l}0.015^{*} \\
{[0.078]}\end{array}$ & $\begin{array}{c}0.015 \\
{[0.107]}\end{array}$ & $\begin{array}{l}0.017^{*} \\
{[0.051]}\end{array}$ & \\
\hline$P U B L I C D E B T$ & $\begin{array}{l}-0.019 \\
{[0.108]}\end{array}$ & $\begin{array}{c}0.133 \\
{[0.112]}\end{array}$ & & & $\begin{array}{l}-0.001 \\
{[0.913]}\end{array}$ \\
\hline$P U B L I C D E B T^{2}$ & & $\begin{array}{c}-0.020^{*} \\
{[0.057]}\end{array}$ & & & \\
\hline$P U B L I C D E B T_{<T 1}$ & & & $\begin{array}{l}-0.017 \\
{[0.176]}\end{array}$ & $\begin{array}{c}0.195 \\
{[0.304]}\end{array}$ & \\
\hline$P U B L I C D E B T_{>T 1}$ & & & $\begin{array}{l}-0.032 \\
{[0.333]}\end{array}$ & & \\
\hline$P U B L I C D E B T_{T 1-T 2}$ & & & & $\begin{array}{c}-0.024^{* * *} \\
{[0.005]}\end{array}$ & \\
\hline$P U B L I C D E B T_{>T 2}$ & & & & $\begin{array}{l}-0.016 \\
{[0.534]}\end{array}$ & \\
\hline$C P I A_{\geq 3.5}(0,1)$ & & & & & $\begin{array}{l}0.070^{*} \\
{[0.063]}\end{array}$ \\
\hline$C P I A_{\geq 3.5} \times P U B L I C D E B T$ & & & & & $\begin{array}{c}-0.016^{*} \\
{[0.083]}\end{array}$ \\
\hline Observations & 320 & 320 & 320 & 320 & 320 \\
\hline Countries & 92 & 92 & 92 & 92 & 92 \\
\hline $\operatorname{AR}(1)$ & 0.005 & 0.011 & 0.006 & 0.017 & 0.002 \\
\hline $\operatorname{AR}(2)$ & 0.564 & 0.657 & 0.81 & 0.978 & 0.781 \\
\hline Hansen OIR & 0.394 & 0.319 & 0.406 & 0.273 & 0.409 \\
\hline
\end{tabular}

Notes: The table reports regression coefficients and, in brackets, the associated robust standard errors. ${ }^{*}$ significant at $10 \%$; ${ }^{* *}$ significant at 5\%; ${ }^{* * *}$ significant at $1 \%$. The model is estimated by Two-Step System GMM, using Stata 11 SE package with XTABOND2 command. The instrument set is built collapsing the lagged values of endogenous variables. Six geographic and five time dummies (included in the regressions but not shown for reasons of space) are taken as strictly exogenous regressors. LEGAL ORIGINS and ETHNIC FRACTIONALIZATION are included as additional instruments. $P U B L I C D E B T$ is taken in the first year of the five-years period. In the spline specification (columns 3 and 4), the discontinuity points $T 1$ and $T 2$ are set, respectively, at a level of public debt equal to 10 and 90 percent of GDP (PUBLIC DEBT equal to 2.398 and 4.511). As diagnostic, the table reports the p-values of the Hansen test for overidentifying restrictions (OIR, the null is the validity of the instrument set) and of the Arellano and Bond autocorrelation tests of first and second order $(\operatorname{AR}(1)$ and $\operatorname{AR}(2)$, the null is no autocorrelation). 